\title{
The Development Trend and Strategy Research on the Retail Industry from the Perspective of Retail Industry Transformation
}

\author{
Dingjie Xu \\ Business Department \\ Chongqing College of Electronic and Engineering \\ Chongqing, China
}

\begin{abstract}
At present, the circulation industry, as a bridge linking production and consumption, is an important connection to promote the production of China's society and is also one of the leading industries of China's economic operation. And the retail industry, as a narrow sense of circulation, plays an important role in the production and consumption of a country. China's retail industry has experienced several stages of development since the reform and opening. China's retail industry has different characteristics at different stages. This article is from the perspective of the transformation of circulation industry to research on our country's retail industry, analyzing present situation and existing problems in the retail transformation, and putting forward the measures of retail development which conforms to trend.
\end{abstract}

Keywords - business transformation; retail industry; innovation

\section{INTRODUCTION}

Since the reform and opening of China's retail industry in 1978, the new development characteristics have been emerging in the business state, and have experienced the rapid development phase after entering the 21st century. But the contradictions and problems follow, to explore more suitable development for China's retail industry and for the development of national economy of our country has important theoretical and practical significance.

\section{TRANSFORMATION PROCESS OF RETAIL INDUSTRY IN CHINA}

\section{A. The Periods of Retail Development in China}

Retail development in our country can be Specific divided into four processes, the first process was reform in 1949 and opening up to the circulation system reform in 1978, retail business modes in this stage is the state department store. The second stage is from 1979 to 1992, which allowed foreign retail enterprises to enter Chinese retail industry. In this stage, there are many economic components such as individual and private retail stores in China's retail industry. The third stage was between 1993 and 2001, a period of rapid development of the chain stores and the development of economic components such as supermarkets in the previous phase. The fourth stage is from 2002 to now. At this stage, shopping center and chain stores have expanded further, while online stores and retail stores have developed.

\section{THE PRESENT SitUATION AND CHARACTERISTICS OF RETAIL DEVELOPMENT IN CHINA}

"2017 China's retail industry development report" pointed out that in 2017, China's macroeconomic situation improved markedly, more perfect policy, Internet, big data and cloud computing, information technology applied more widely. Profound changes in consumer demand create new supply and new model of retail industry. In 2017, the online retail enterprise integrated comprehensively in-depth with off line operation, multiple social consumption scenarios, collaborative one-step service, intelligent and efficient supply chain system will be increasingly obviously.

\section{A. The Growth of Entity Retail Sales Is obviously Differentiated}

Homogenized competition, distributaries of online retail, profound changes on customer needs, these are the unfavorable situation. In recent years, circulation industry was gradually promoting structural reform, transformation and upgrading of entity retail. The growth rate of different formats is obvious, so is the differentiation in transition. The growth of sales was 3.1 per cent and 1.3 per cent respectively, while the rate of growth in department stores was 2.1 percentage points lower than that of the previous year. The growth rate of specialist stores was 2.8 percentage points higher than that of the previous year.

\section{B. Network Retail Tends to Mature}

China's online retail is entering into the mature stage in recent years with Steady growth. With the slow stabilized growth, online retail enterprises compete from stock of incremental expansion into stock development, quality acceleration, service level improvement, and shopping experience enhancement. According to the national bureau of statistics, China's online retail sales reached 5155.6 billion yuan in 2016 , an increase of $26.2 \%$ this year, a growth decrease of 7.1 percentage points compared with the previous year. The online retail sales of entity goods were 419.44 billion Yuan, up to 25.6 percent, and the growth rate was 6 percentage points 
lower than the previous year. Online retail sales of entity goods account for $12.6 \%$ of total retail sales of consumer goods, up 1.8 percentage points from the previous year.

To sum up, with "Internet +", the popularization and the tre nd of online fusion, the future of online retail will continue rapi $\mathrm{d}$ growth momentum; become an important force in China's ret ail industry growth.

\section{THE DEVELOPMENT TREND OF RETAIL INDUSTRY IN CHINA}

\section{A. Online and Offline Integrated Development Model}

An online and offline integrated mode is the requirement of the transformation and upgrading of the traditional retail. Concerning the traditional retail formats in China, it has the phenomenon of frequently shutters, visible pressure of the current retail operation is unprecedented, the most effective and revitalized strategy is blending online and offline retailing in a vague situation.

Meanwhile, with the development of the O2C model and the development of "Internet + ", the broad development prospect of online retailing can pull the current traditional retail business. At the same time, due to the high growth of Internet retail and high investment, it will face a bottleneck period. And as e-commerce continues to expand consumers will be more critical. Currently online and offline fusion has begun, and the future will be continued to deepen.

It will accelerate the development of online and offline, gradually in the management mode, operation mode, such as marketing management and service system for comprehensive coordination. Under the online and offline integration and development mode, the price strategy, personalized interaction, cross-channel marketing, logistics and after-sales service of both channels will be innovated with the integration. In the future, online and offline integration will help to transform the negative growth of real retail profits into a comprehensive platform integrating shopping, leisure entertainment and social networking. Consumers can also experience the same and highquality services from different retail formats and platforms.

\section{B. Adjustment of Strategic Layout of Entity Retail Stores}

To reduce operating costs and adapt to the trend of deepening $\mathrm{O} 2 \mathrm{O}$ integration, entity retail formats will make strategic layout adjustment, so in the future, some poor business entity retail stores will also put up the shutters. On the other hand, entity retail enterprises will also speed up the distribution and optimization of logistics distribution centers for service network retail, to take the lead of online and offline integration. The traditional retail industry will still have great development space in the future. Since China's consumption is only $5 \%$ of GDP, there is still a gap comparing with the developed countries. Traditional development mode apparently can't meet the demand of the consumer market, so in the future, retail entity stores will be converged with further change management ideas under the premise of network operation. Entity stores return to the nature of retail, and convert the consumers as the center. Price of The entity retail in our country is on the high side. It makes the consumers divert to online retail channels, and pricing strategy of entities stores in the future is likely to be adjusted to adapt to market development trend, or strengthen the entity service function of retail formats, or improved customer consumption experience.

\section{Acceleration of Supply Chain Integration}

Acceleration of $\mathrm{O} 2 \mathrm{O}$ modes will further promote the merger and reorganization of retail enterprise organization, speed up the integration of supply chain between manufacturers, wholesalers and retailers. Shaping a new alliance and collaboration, through information sharing, optimized all parties' benefits.

\section{CHINA’S RETAIL INDUSTRY INNOVATIVE COUNTERMEASURES}

\section{A. Entity retail Industry Is Centered on Consumption}

The current situation in entity retail industry requires a trans ition to reorganizing and reconstructing the goods to bring the e ntity retail price back to a reasonable price. The essence of retai 1 is to allow buyers and sellers to trade fairly, and customers pa $y$ for goods and services, while merchants have the responsibili ty and obligation to provide withthe goods and services. On the one hand, businesses should use price levers to rally their popu larity, specify a more reasonable price for their goods.on the ot her hand to enhance the customer experience, such as strengthe ning service function oftheentity retail formats, in the original e ntity can provide services based on the experience of retailing $f$ orms, add some servicestation, installWIFI equipment, open $\mathrm{W}$ ireless payment,collect customer data torefine marketing and $\mathrm{m}$ anagement and all can be used as a management method into $t$ he new way of thinking.

\section{B. Traditional Retail Enterprises Realize the Whole Channel Operation Mode}

The whole channel operation mode is a business model of traditional retail enterprises to meet the trend of retailing. From a consumer perspective, consumers want to have a consistent shopping experience from different consumer channels. However, from the perspective of the enterprise, the whole channel operation can give enterprises benefits from complement each other and promote the transformation and development of enterprises. At the same time, the whole channel development is also the entry point of online and offline integration of traditional entity retail business. All channels development model can make the enterprise have stronger ability of resource integration, for online business integration and vertical integration of supply chain, and control of consumers will be more at ease. Some fresh retail, for example, can deepen the chain services to improve consumer experience of viscosity, and also enhance consumer $\mathrm{O} 2 \mathrm{O}$ experience, enterprises can try to establish fresh traceability platform APP, of which consumers purchase the fresh product in the entity retail store while scan the QR code to get the place of origin and testimony results.

For some traditional retail enterprises that have tried the whole channel development, they need to expand the sales volume of all channels and arrange the $\mathrm{O} 2 \mathrm{O}$ model 
reasonably. It also actively introduces the talents of ecommerce talents, information technology talents and logistics talents to further promote the development of the whole channel development mode.

\section{Actively Setting up the Internet of Things to Promote Online Retail to Offline Development}

For online retail, it is necessary to expand the Internet of things. Because the network retail is relying on the logistics to deliver the goods, the enterprise that carries on the network retail has the perfect warehouse network and the distribution network. But if Internet retail is to expand offline, it must rely on the powerful Internet of things to expand market share. In particular, it is possible to expand the logistics system from several aspects, and optimize the network of scientific planning things, from warehouses, logistics routes and distribution. The second is to speed up the construction of logistics informatization, strengthen the research and development of logistics information system, and comprehensively apply the logistics to improve logistics distribution efficiency. Third, strengthen cooperation with offline enterprises or platforms. For example, for fresh distribution, we can cooperate with large and fresh distribution enterprises, and use the advantages of our own Internet of things to carry out the sale of fresh products.

\section{CONCLUSION}

To sum up, for more than 30 years process of changes of the retail industry experience, with distinct characteristics of the era, traditional retail business operation with competitive pressure at the same time also has a new development opportunity. So, in the future, traditional retail business must carry on the innovation and development; deepen the integration of online retail, break the bottleneck of traditional retail, the stable development of China's retail industry can be in parallel with online operation.

\section{REFERENCES}

[1] ShenyanZhu,the analysisofretail business transition'sprocess and mecha nism[D]Zhejiang University of Commerce and Industry ,2012

[2] PingpingWen,Study on the change of retail industry and structural optim ization in China [D]. Tianjin University of finance and economics, 2013

[3] JingWang Research on retail business transition in the process of urbanization [D]. Jinan University, 2011

[4] JuanWang, Siwei Liu. Transformation and innovation of retail industry in China: 1978-2010[J]. Hunan social science, 2012(6)

[5] Congcai Xu, Zhaoxun Sheng, major retailers dominate the industrial chain: the new direction of China's industrial transformation and upgrading [J]. Finance and economics, 2012(1)

[6] Hongyan Lu. Research on the transformation and upgrading of the circulation industry under the "new normal" economy $[\mathrm{J}]$. Research on commercial economy, 2015(6) 